Vol. 2, No. 1, 2020

https://doi.org/10.23939/jtbp2020.01.094

Yaroslav Kotsiy, Myron Gogol, Ivan Peleshko, Igor Ivaneyko

\title{
INVESTIGATION OF THE EFFECT \\ OF WORKING MOVEMENT LENGTH ON THE EFFICIENCY OF THE EXCAVATORS
}

\author{
Department of Building Production, \\ Lviv Polytechnic National University \\ yaroslavkotsiy@gmail.com
}

(C) Kotsiy Y., Gogol M., Peleshko I., Ivaneyko I., 2020

The question of the effect of working length on the performance of one-bucket excavators, in particular for their production, dedicated to the research of many authors. As one of the coefficients of the variable time factor for determining operational performance, the coefficient of impact of movement is proposed. When determining the cycle life of excavators with different equipment, ranges of coefficient changes were set, which takes into account the length of the working movement. It is necessary to consider the technological capabilities of the machines in their operation to achieve the required quality of work on object considering to the increasing use of new machines and mechanisms, the decline in the multi-operability of earthmoving production. The purpose of this article is to increase the efficiency of the using of excavation complexes in the arrangement of exavation face, providing the required quality of work. It should be noted that ensuring and maintaining the reached level of performance required quality to reduced efficiency of the main construction machines, including their productivity. In addition to the complexity of the three-dimensional characteristics of the object, the magnitude of the operational productivity of the leading machines of the complexes are influenced by a number of different factors, among which it is possible to distinguish the technological parameters of the machines. One of the most important technological parameters of the operation of single-bucket excavators, which also affects the quality of work during the cleaning of the ditches, is the length of the working movement and the width associated with it. Currently, the choice of parameters is made on the basis of empirical dependencies and practical recommendations and often it is controversial, especially for excavators equipped with a backhoe.

Key words: schemes of the work of excavators, time on working shift, the technical and operational performance of the excavators.

\section{Introduction}

Development of excavation face with a backhoe equipped with a shovel can be performed frontal (face) penetration or lateral penetration with preliminary development of the pioneer trench.

When developing a narrow pit with a frontal drill, the excavator develops it to a given width, moving in a straight line, when working with a frontal extended drill - moving with two frontal penetrations, a zigzag or cross-end moves.

Wide excavation face are developed in the frontal way to the pioneer trench with the further development of the soil by lateral penetrations. 
The choice of the scheme of movement of the excavator is made depending on the width of the pit and the technological parameters of the working equipment of the excavators, in particular, the maximum digging radius.

\section{Target of this article}

The purpose of this work is to increase the efficiency of the use of excavation complexes in the arrangement of ditches, which provide the required quality of work.

\section{Techniques used}

For hydraulic excavators equipped with a backhoe, it varies up to $5 \%$ depending on the relative length of movement, for mechanical driven excavators - up to $20 \%$.

The optimal value of the movement, equal to 0.75 maximum possible for a given depth of digging movement value (Chernenko, 2002, Yarmolenko, 2005).

$$
Q_{\text {s }}=Q k_{y} k_{B},
$$

where $Q, Q_{b}$ respectively the operational and technical performance of the excavator, $\mathrm{m}^{3} / \mathrm{s} ; k_{y}-$ the coefficient of control of the machine depending on the skill of the driver (0.89 ... 0.98) (Chernenko, Galimullin \& Chebanov, 1989, Donskoy, 1976); $k_{B}$ - variable time utilization factor taking into account the impact of excavator working displacements $\eta$.

In general, the impact of the excavator movement can be represented:

$$
\eta=\frac{H l_{\eta} B_{c p} / Q}{H l_{\eta} B_{c p} / Q+l_{\eta} / U+t_{n e p}}
$$

where $\eta$ - coefficient impact of excavator movement; $H$ - the depth of the ditches, $\mathrm{m} ; l_{\eta}-$ length of working movement, $\mathrm{m} ; B_{c p}$ - the average width of the ditches, $\mathrm{m}$; $U$ - speed of excavator, $\mathrm{m} / \mathrm{s}$ (Akimova, Ammosov, Badin \& Mescheryakova, 1987).

Optimized length of movement closely related to the geometric parameters of the excavation face.

Given this value, the effect of the displacement coefficient was determined for ditches of varying depth, however, there is an inverse relationship between the length of movement and the average width of the excavation face.

On the example of excavators EO-5122, E-5015a, EO-3322v, performing frontal and side penetrations, the values of the coefficient are given in the range from the minimum to the maximum possible length of the machine for this brand of machine (Fig. 1).

The analysis of the above graphs shows that the intensity of change of the coefficient of influence of movement increases with the decrease of the depth of the ditches.

According to the recommendations, the length of the excavator with a capacity of $0.5 \mathrm{~m}^{3}$ (E-5015A) bucket should be $1.4 \mathrm{~m}$ (Yarmolenko, 2007).

In this case, $\eta$ is 0.936 for the ditches with a depth of $H=0.5 \mathrm{~m}$ and $\eta=0.981$ for $H=2.0 \mathrm{~m}$.

The length of the working movement, determined according to our proposed method, respectively, is $2.5 \mathrm{~m}(\eta=0.856)$ for $H=0.5 \mathrm{~m}$ and $1.8 \mathrm{~m}(\eta=0.983)$ for $H=2.0 \mathrm{~m}$. 


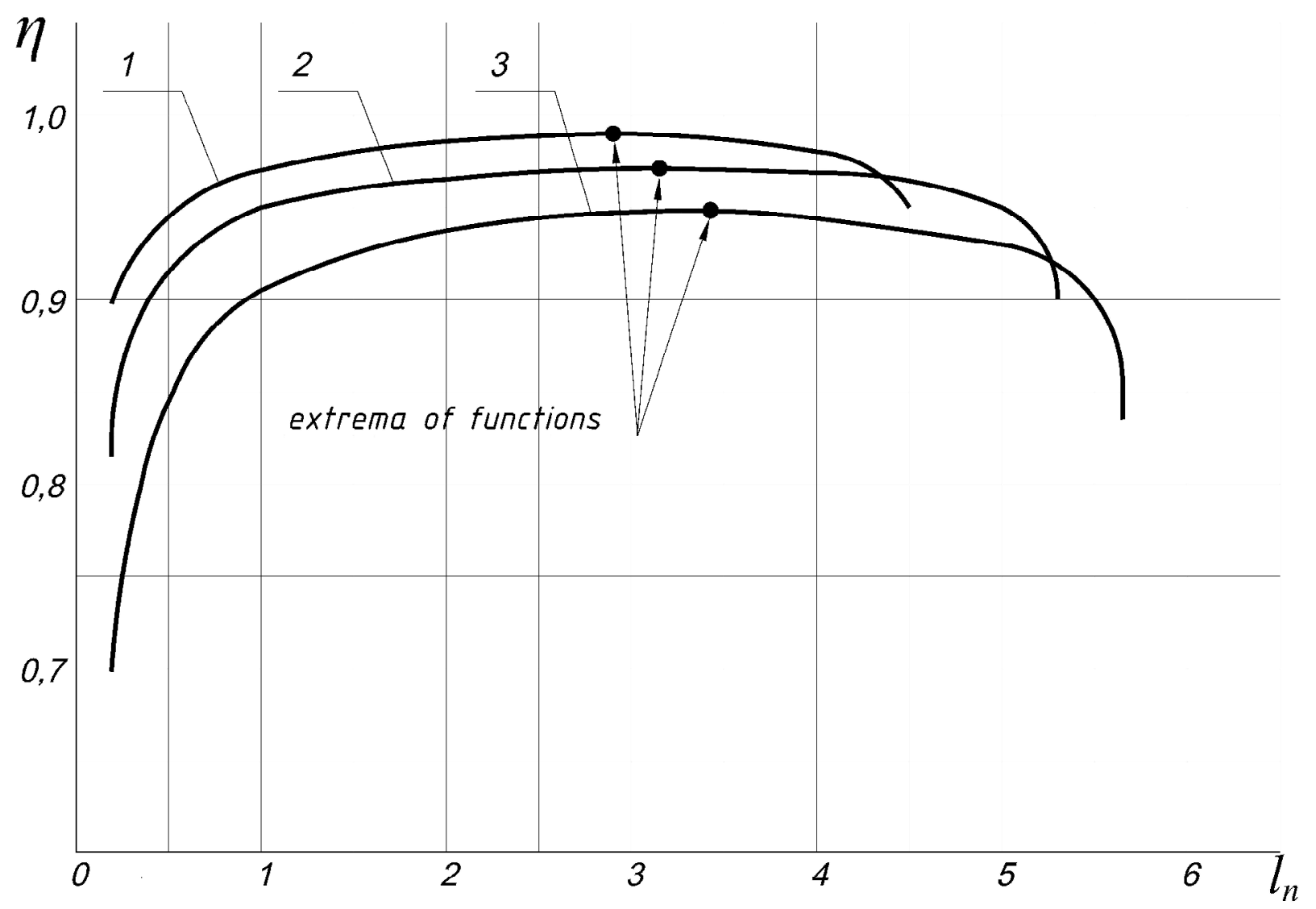

Fig. 1. Dependence of $\eta$ on In for EO-5122 $\left(q=1.6 \mathrm{~m}^{3}\right)$ when arranging pioneer trenches of ditches: $1,2,3$ - at a depth of $2 \mathrm{~m}, 1 \mathrm{~m}, 0.5 \mathrm{~m}$, respectively

The nature of the dependence $\eta-l_{\eta}$ is significantly different for the frontal and lateral diggings of the excavator. In the case of excavators with frontal penetrations, there are three sections with different intensity changes:

section I - less than $0.2 l_{n}^{\max }$,

section $\mathrm{II}$ - in the range $0.2 \div 0.87 l_{n}^{\max }$,

section III - more than $0.87 l_{n}^{\max }$,

where $l_{n}^{\max }$ is the maximum possible length of movement of this excavator brand for a given digging depth, m.

For ditches of a particular depth, the largest changes are observed in the I and III sections (from 0.695 to 0.981$)$.

In the second section, the coefficient of influence of movement changes its absolute value within $3 \%$ (Ivanik, Vihot, Pozhar, Ivanik \& Vybranets, 2013). When working excavators, the side penetrations can distinguish two sections, differing in the intensity of the coefficient $\eta$ : the first section less than $0.2 l_{n}^{\max }$ noticeable decrease with and the second - more than $0.2 l_{n}^{\max }$, where the value of $\eta$ varies within $3 \%$.

Hence the conclusion that the purpose of the maximum length of movement does not significantly affect the performance of the excavator when the side aisles. 
Thus, the choice of the length of the working movement should be made on the basis of a given depth of the pit, and with increasing depth of the pit its impact is reduced. This is confirmed by the dependence of the change in the magnitude of the technical productivity and the coefficient $\eta$, which increases for shallow ditches.

The physical meaning of the objective function (2) is the desire to develop a maximum volume of soil from a single excavator stand (Zarubin, 1984).

The largest amount of soil that is being developed can be achieved within the face of the slaughter by assigning a rational movement length at which function (2) has an extreme.

In Fig. 1 shows the change in the volume of soil developed from one parking lot, when changing the length of movement from the minimum (at the bottom of the curves) to the maximum value for ditches of different depths (Isakhanov, 1985).

When performing planning and clearing works, the choice of the length of the excavator's movement depends on the length of the planned area in the area of work equipment. The average length of the possible horizontal planning trajectory is $80 \%$ of the length of the trajectory, determined by the size of this zone, that is, the maximum movement length for a given digging depth with the back shovel (Dehtyarev, Reish \& Rudensky, 1987).

Therefore, in the case of a slight change in the impact coefficient of movement for the pit of a given depth in order to improve the quality of work, the length of the movement should be determined taking into account the length of the planned section.

\section{Conclusions}

As a result of the calculations, it was found that the rational length of working movement for excavators with hydraulic drive, determined by the proposed method, respectively, is:

for frontal driving $l_{n}^{f}=0.6 l_{n}^{\max }$,

for lateral driving $l_{n}^{l}=0.75 \div 0.8 l_{n}^{\max }$,

$l_{n}^{f}, l_{n}^{l}$ - the rational length of the working movement of the excavator in frontal and lateral driving.

At the same time the condition of fulfillment of the possible horizontal trajectory of planning is observed and the inspection by the driver of the bottom of the pit is provided.

\section{References}

Chernenko V. K. (2002) Tekhnolohiia budivelnoho vyrobnytstva, [Technology of construction production], Higher School, 388 p. [in Ukrainian].

Yarmolenko M. G. (2005) Tekhnolohiia budivelnoho vyrobnytstva, [Technology of construction production], Kiev, Higher School, 328 p., [in Ukrainian].

Yarmolenko M. G. (2007) Tekhnolohiia budivelnoho vyrobnytstva. [Technology of construction production] Workshop. Kiev, Higher School, 342 p. [in Ukrainian].

Isakhanov G. V. (1985) Osnovy nauchnykh issledovanyi v stroytelstve [Fundamentals of research in construction], Kiev, Higher School, 208 p. [in Russian].

Ivanik I. G., Vihot S. I., Pozhar R. S., Ivanik J. I., Vybranets Y. Y. (2013) Osnovy rekonstruktsii budivel i sporud [Basics of reconstruction of buildings and structures], Lviv, Lviv Polytechnic publication, $276 \mathrm{p}$. [in Ukrainian].

Akimova L. D., Ammosov N. G., Badin G. M. etc. By ed, G. M. Badin, A. V. Mescheryakova. (1987) Tekhnolohyia stroytelnoho proyzvodstva, [Technology of building production], Textbook., L., Stroyizdat, 606 p., [in Russian].

Chernenko V. K., Galimullin V. A., Chebanov L. S. (1989) Proektyrovanye zemlianykh rabot. Prohramyrovannoe posobye [Earthwork design. Programmed allowance], Kyiv, High school, 159 p. [in Russian].

Dehtyarev A. P., Reish A. K., Rudensky S. I. (1987) Kompleksnaia mekhanyzatsyia zemlianykh rabot [Complex mechanization of earthworks], Moskow, Stroyizdat, 334 p. [in Russian]. 
Zarubin V. N. (1984) Intensyfikatsiya stroyky [Intensification of construction], Moskow, Sovetskaya Rossyya, 144p. [in Russian].

Donskoy V. M. (1976) Mechanization of earthworks of small volumes [Mekhanizatsiya zemlyanykh rabot malykh obyemov], Leningrad, Stroyizdat, 160 p. [in Russian].

Я. Й. Коцій, М. В. Гоголь, І. Д. Пелешко, І. Д. Іванейко Національний університет "Львівська політехніка", Кафедра будівельного виробництва

\section{ДОСЛІДЖЕННЯ ВПЛИВУ ДОВЖИНИ РОБОЧОГО ПЕРЕСУВАННЯ НА ЕФЕКТИВНІСТЬ РОБОТИ ЕКСКАВАТОРІВ}

(С Кочій Я. Й., Гоголь М. В, Пелешко І. Д., Іванейко І. Д., 2020

Питанню впливу довжини робочої пересування на ефективність роботи одноківшових екскаваторів, зокрема, на їх виробництво , присвячено дослідження багатьох авторів. Як однин із співмножників коефіцієнта використання змінного часу для визначення експлуатаційної продуктивності запропоновано коефіцієнт впливу пересування. При визначенні тривалості циклу роботи екскаваторів iз різним устаткуванням встановлено діапазони змін коефіцієнта, що враховує довжину робочого пересування. 3 урахуванням зростаючого застосування нових машин і механізмів, зниження багатоопераційності виробництва земляних робіт необхідно враховувати складність спорудження і технологічні можливості машин для досягнення необхідної якості робіт на об'єкті. Метою роботи $є$ підвищення ефективності застосування екскаваторних комплексів при влаштуванні котлованів, що забезпечують необхідну якість виконання робіт. Слід зазначити, що забезпечення і підтримання на досягнутому рівні необхідної якості виконання робіт призводить до зниженої ефективності роботи основних будівельних машин, зокрема їх продуктивності. Крім складності об'ємно-планувальних характеристик об'єкта, на величину експлуатаційної продуктивності провідних машин комплексів впливають такі фактори, як технологічні параметри роботи машин. Одним з найважливіших технологічних параметрів роботи одноківшових екскаваторів, який впливає також на якість виконання робіт при зачистці котлованів, є довжина робочого пересування і взаємопов'язана 3 нею ширина проходки. Сьогодні вибирають параметри за емпіричними залежностями, i практичними рекомендаціями, які часто мають заперечний характер, особливо для екскаваторів, обладнаних зворотною лопатою.

Ключові слова: схеми роботи екскаваторів, час на робоче пересування, технічна та експлуатаційна продуктивність екскаваторів. 